\title{
FORUM
}

Submitted 03.17.2020. Approved 11.30.2020

Evaluated through a double-blind review process. Guest Editors: Luciana Marques Vieira, Marcia Dutra de Barcellos, Gustavo Porpino de Araujo, Mattias Eriksson, Manoj Dora and Daniele Eckert Matzembacher

Original version | DOI: http://dx.doi.org/10.1590/S0034-759020210503

\section{REDUCING FOOD WASTE THROUGH LEAN AND SUSTAINABLE OPERATIONS: A CASE STUDY FROM THE POULTRY INDUSTRY}

\author{
Redução do desperdício de alimentos por meio de operações sustentáveis e enxutas: Estudo de \\ caso do setor avícola
}
Reducción del desperdicio de alimentos mediante operaciones lean y sostenibles: Estudio de caso de la industria avícola

\author{
Yigit Kazancoglu1 | yigit.kazancoglu@yasar.edu.tr | ORCID: 0000-0001-9199-671X \\ Esra Ekinci1 | esra.ekinci@yasar.edu.tr| ORCID: 0000-0003-2609-7763 \\ Yesim Deniz Ozkan Ozen ${ }^{1}$ | yesim.ozen@yasar.edu.tr | ORCID: 0000-0003-4520-6590 \\ Melisa Ozbiltekin Pala1 | melisa.ozbiltekin@yasar.edu.tr | ORCID: 0000-0002-1356-3203
}

${ }^{1}$ Yasar University, Faculty of Business, Logistics Management Department, Esmirna, Turkey

\begin{abstract}
The growing need for solving the problem of food waste for tackling the survival of the planet and humankind is encouraging researchers to seek sustainable operations that alter the conventional methods that are currently in use in the food industry. Lean thinking has been used in this study to propose sustainable operations that incorporate social, economic, and environmental aspects and to handle the multidisciplinary and complex nature of reducing food waste. The value stream mapping methodology has been employed to explain food waste and generate drivers and to observe the end-to-end system flow. Since most of the waste is observed in upstream operations in emerging economies, one of the biggest meat-processing companies in Turkey is studied for illustrating the proposed methodology. As a result of the model, lean and sustainable food operations are suggested considering social, economic and environmental aspects.
\end{abstract}

KEYWORDS | Lean management, sustainability, food waste, value stream mapping, emerging economy.

\section{RESUMO}

A crescente necessidade de resolver o problema do desperdício de alimentos para a sobrevivência do planeta e da humanidade incentiva os pesquisadores a buscarem operações sustentáveis que alterem os métodos convencionais atualmente em uso na indústria de alimentos. Neste estudo, o pensamento enxuto foi utilizado para propor operações sustentáveis incorporando aspectos sociais, econômicos e ambientais e para lidar com a natureza multidisciplinar e complexa da redução do desperdício de alimentos. A metodologia de mapeamento do fluxo de valor foi empregada para explicar os fatores geradores de desperdício de alimentos e para ver o fluxo do sistema de ponta a ponta. Como a maioria dos resíduos pode ser observada em operações a montante em economias emergentes, a metodologia proposta é ilustrada em uma das maiores empresas de carne da Turquia. Como resultado do modelo, operações alimentares enxutas e sustentáveis foram sugeridas considerando aspectos sociais, econômicos e ambientais.

PALAVRAS-CHAVE / Gestión eficiente, sostenibilidad, desperdicio de alimentos, mapeo de flujo de valor, economía emergente.

\section{RESUMEN}

La creciente necesidad de resolver el problema del desperdicio de alimentos para la supervivencia del planeta y la humanidad alienta a los investigadores a buscar operaciones sostenibles que alteren los métodos convencionales que se utilizan actualmente en la industria alimenticia. En este estudio, se ha utilizado la filosofía lean para proponer operaciones sostenibles que incorporen aspectos sociales, económicos y ambientales y para manejar la naturaleza multidisciplinaria y compleja de la reducción del desperdicio de alimentos. La metodología de mapeo de flujo de valor se ha empleado para explicar los generadores del desperdicio de alimentos y para ver el flujo del sistema de extremo a extremo. Dado que el mayor desperdicio se observa en las operaciones iniciales en las economías emergentes, se estudió una de las compañías de carne más grandes de Turquía para ilustrar la metodología propuesta. Como resultado del modelo, se han sugerido operaciones alimentarias magras y sostenibles que consideren aspectos sociales, económicos y ambientales.

PALABRAS CLAVE I Gestión eficiente, sostenibilidad, desechos alimentarios, mapeo de flujo de valor, economía emergente. 


\section{INTRODUCTION}

The world population is expected to reach 9.5 billion by 2075 , which is motivating researchers to investigate sustainable operations for social, economic, environmental and political issues (Institution of Mechanical Engineers, 2013). A basic standpoint for solving interrelated problems in these areas is dealing with finding enough food supply for 1.7 billion additional people by the end of the century. Total production worldwide is approximately four billion metric tons per year, but 30-50\% of the food produced is lost for various reasons (Institution of Mechanical Engineers, 2013; Kumar, Mangla, Kumar, \& Karamperidis, 2020). Food waste starts with initial agricultural production for consumption by end-users and losses are high both in industrialized and emerging economies. In third world and emerging economies, food losses occur mostly in the farming, post-harvest and processing stages, whereas in industrialized countries waste occurs predominantly on the retail and customer sides (Food and Agriculture Organization of the United Nations [FAO], 2011a; Institution of Mechanical Engineers, 2013). If food loss can be reduced, it may be possible to feed an additional two billion people, since globally we already produce food enough for 10 billion people (Gimenez, Shattuck, Altieri, Herren, \& Gliessman, 2010; World Food Program USA [WFPUSA], 2019). Continuing with the existing conventional methods both in agriculture and livestock production, however, will shortly lead to unsustainable outputs, so humankind must seek solutions for reducing food loss and improving food production processes (Castellini, Bastianoni, Granai, Bosco, \& Brunetti, 2006; Gimenez et al., 2010; Kumm, 2002). Therefore, in the United Nations' sustainable development plan for 2030, ending hunger by providing sufficient, safe, affordable, and nutritious food, and reducing food waste starting from the production stage through to consumption are two main objectives for the welfare of humanity and the planet. It is understood that sustainable operations in food waste management are a crucial instrument for transforming sustainable societies and for the well-being of humans (Ingrao, Faccilongo, Gioia, \& Messineo, 2018).

According to Thyberg and Tonjes (2016), food waste is a complex and interdisciplinary problem, which can be resolved by developing sustainable policies for a diverse range of waste generating drivers. On the other hand, Lean Thinking, which is applied in various fields from production to service systems, is a discipline comprising a collection of principles and philosophies that are used to eliminate waste and non-value adding activities. Therefore, the solutions being offered can cover various areas, including the social, economic, and environmental even within the same context. Systematically applying lean disciplines in the food industry is a common methodology for eliminating waste (Vlachos, 2015). Although the main causes of waste might be incorrectly assumed to be food miles and plastic packaging, in reality it has been discovered that the leading sources of waste are overproduction, overstocking, excessive transportation, waiting times, unnecessary movement throughout the supply chain, and production problems (such as poor-quality materials and equipment, incorrect procedures, etc.), all of which can be dealt with by way of lean thinking (Gooch et al., 2010). Value Stream Mapping (VSM), as a useful methodology for investigating value-adding and non-valueadding activities, and for offering solutions for eventually eliminating waste generating activities, has been employed relatively commonly in literature. Proposing solutions for reducing the waste that has implications for social, economic, and environmental aspects may also result in sustainability being achieved in the system of interest.

Our aim in this study is to explain the following research objectives:

- To propose a holistic approach for clarifying waste generating drivers while reviewing the system processes;

- To suggest solutions that alter conventional methods by way of sustainable operations based on lean philosophy; 
- To explain how VSM can be a convenient methodology for recommending multidisciplinary solutions for food waste that can cover the three aspects of sustainability, which are economic, social, and environmental.

The VSM model has been used in this study to suggest lean and sustainable operations that cover social, economic and environmental aspects. With the help of the proposed solutions, it is proved that lean thinking is a suitable philosophy for reducing food waste. Since food waste occurs in upstream operations in emerging economies, the study focuses on one of the biggest meat companies in Turkey. Implementing VSM is suggested as a way of improving sustainable operations in food supply chain operations. The future state map is presented, which is followed by implications for both policymakers and managers.

Section 2 presents food waste in an emerging economy and reviews the literature dealing with lean management in the food industry. Section 3 outlines the research gap that exists with regard to lean and sustainable food operations. Section 4 describes VSM, while a case study in the poultry industry is explained in Section 5 . Section 6 presents the contributions of the study to sustainable operations. Section 7 and Section 8 provide the managerial implications and the conclusion, respectively.

\section{FOOD WASTE IN AN EMERGING ECONOMY}

Food waste is a growing problem all around the world and according to the FAO Report (FAO, 2011b), From Farm to Fork, one-third of the world's food production is lost or wasted (Zhao et al., 2020). The excessive and unnecessary use of water and energy, and the greenhouse gas emissions caused by the production and distribution process, and the growth in population and demand all result in increasing food waste (Mangla et al., 2018). Food loss and food waste refer to reductions in quantity in the supply chain of the food that is produced, especially food for human consumption (FAO, 2011a). These losses and waste occur throughout the entire supply chain from field to table, and involve production, processing, packaging, transportation, and distribution (Ju, Osako, \& Harashina, 2017; Parfitt, Barthel, \& Macnaughton, 2010). Food loss and waste occur both in developed and emerging countries. While food loss and waste occur mostly in the retail and consumption areas in developed countries, the most significant food loss and waste in emerging countries occurs in the early and middle stages of the food supply chain (Verma et al., 2019). Developed countries consume food more than 200 million tons of food every year, mostly in the retail and consumption areas. Between 6 and11 $\mathrm{kg}$. of waste per person are generated in Africa and South Asia, while there are between 95 and $115 \mathrm{~kg}$. of food waste per person in Europe and North America every year (Ishangulyyev, Kim, \& Lee, 2019). Encouraging consumers to buy more food than they need in markets with high-quality standards leads to food waste in developed countries (Wunderlich \& Martinez, 2018).

On the other hand, in emerging countries like Turkey (Kayıkcı, Ozbiltekin, \& Kazancoglu, 2019), the main causes of food waste are a lack of knowledge and technology during the harvesting process, a lack of appropriate infrastructure, a lack of knowledge of the post-harvest stage, and packaging processes (Wunderlich \& Martinez, 2018). In the farming process, farmers suffer great losses during production because of early harvesting, storage, insect attack and careless use (Östergren et al., 2014). In the harvesting process, insufficient storage conditions result in bad consequences, such as insect infestation and the formation of mold, leading to food loss (Gustavsson, Cederberg, Sonesson, Otterdijk, \& Meybeck, 2011; Ju et al., 2017). Decay organisms develop and increase with the emergence of fungi and diseases due to high temperatures and humidity after the harvest, which can lead to the 
whole crop deteriorating (Verghese, Lewis, Lockrey, \& Williams, 2015). Losses occur in processing plants due to a lack of technologies and insufficient facilities (Kumar \& Kalita, 2017). According to the statistics, almost 50 percent of food losses occur at the post-harvest and processing levels (Kummu et al., 2012).

Turkey, an important emerging economy, has a growing population of more than 80 million inhabitants (United Nations High Commissioner for Refugees [UNHCR], 2019). This growth is leading to an increased demand for food for the country's consumers. Turkey is ranked among the top 20 countries in the world in agriculture, producing milk, wheat, and other crops (FAO, 2015). While annual food production in Turkey is calculated to be 122.9 $\mathrm{Mt} / \mathrm{y}$, the amount of food wasted is calculated at $16 \mathrm{Mt} / \mathrm{y}$ (The Standing Committee for Economic and Commercial Cooperation of the Organization of the Islamic Cooperation [COMCEC], 2017).

Like other emerging economies, food loss and waste in Turkey occur during all processes in the supply chain, from production to consumption (Tatlıdil, Dellal, \& Bayramoglu, 2013). Food waste is also a growing issue in the country, and has economic, environmental, and social consequences (Yıldırım et al., 2016). According to the statistics, every year, some 26 million tons of food are thrown away in Turkey, which corresponds to almost 215 billion TL (Turkish Republic Ministry of Industry and Trade, 2018).

Lean approaches can be a solution for reducing food waste in emerging economies, because they not only minimize waste, but also increase operational efficiency. The following section contains a review of the literature on lean management in the food industry.

\section{Lean management in the food industry}

Lean management is the approach used for presenting value from the customers' perspective, for continuously developing an organization's processes, and for avoiding waste (Chronéer \& Wallström, 2016). It is a management method for companies that try to adapt to current market conditions by way of functional and organizational changes (Dekier, 2012). Lean management also results in reducing costs, increasing customer interactions, quality, enhanced employee morale and improvements in culture and the use of push and pull systems (Liu, Yang, \& Xin, 2019).

Although lean management is an essential for all industries, knowledge about lean practices and how to implement them in the food industry is a very narrow area. There is still a gap in lean practices and developing effective management in the food industry within the concept of lean management (Sreedharan \& Raju, 2016). Moreover, increased pressure from consumers and competition between firms have recently affected the implementation of lean management (Dora, Goubergen, Kumar, Molnar, \& Gellynck, 2014).

Lean management in the food industry is essential since the industry is a changeable sector (Singh, Luthra, Mangla, \& Uniyal, 2019), in which production batches and processing times at the production stages vary because of seasonality and the shortness of shelf-life factors (Dora et al., 2014; Liu et al., 2019). In contrast with other industries, many food and agricultural products are harvested at certain times of the year and must be processed in large batches regardless of the frequency of customer demand (Liu et al., 2019; Mahalik \& Nambiar, 2010). Therefore, it is difficult to produce on time within this sector. Lean management aims to reduce costs by increasing quality in the industry. With the help of lean management, the customer value of food companies increases though the company costs of food industry decreases (Lehtinen \& Torkko, 2005).

In considering the literature review, there are many studies about lean management in the food industry. These studies focus on different parts of this industry, such as manufacturing, supply chains and processing. Exhibit 1 provides an overview of the literature about lean management in the food industry. 
FORUM | REDUCING FOOD WASTE THROUGH LEAN AND SUSTAINABLE OPERATIONS: A CASE STUDY FROM THE POULTRY INDUSTRY

Yigit Kazancoglu | Esra Ekinci | Yesim Deniz Ozkan Ozen | Melisa Ozbiltekin Pala

Exhibit 1. The literature review of lean management in the food industry

\begin{tabular}{|c|c|c|}
\hline Author(s) & Method(s) & Focus Area \\
\hline Cox and Chicksand (2005) & Case Study & Food Industry \\
\hline Lehtinen and Torkko (2005) & Value Stream Map & Food Manufacturing \\
\hline Taylor (2006) & Case Study & Agri-food Supply Chain \\
\hline Gellynck and Molnar (2009) & Combined Taxonomy Compilation & Organizational Structures in the Food Industry \\
\hline Scherrer-Rathje et al. (2009) & Case Study & Food Processing Machines \\
\hline Perez et al. (2010) & Case Study & Food Supply Chain \\
\hline Testa (2010) & Value Stream Map & Food Processing \\
\hline Zarei et al. (2011) & Fuzzy Quality Function Deployment (QFD) & Food Supply Chain \\
\hline Manzouri et al. (2013) & Survey & Food Supply Chain \\
\hline Noorwali (2013) & $\begin{array}{l}\text { Lean Approach, Taguchi, Simulation, and } \\
\text { Correlation }\end{array}$ & Food Flow Processing \\
\hline Besseris (2014) & Experimental Procedure & Food Product Improvement \\
\hline Chaplin and O'Rourke (2014) & Observation & Food Production \\
\hline Lopes et al. (2015) & Case Study & Process Innovation \\
\hline Sreedharan and Raju (2016) & Systematic Literature Review & Different Industries \\
\hline Ali et al. (2017) & Theoretical sampling & Food Production \\
\hline Kezia et al. (2017) & Desk Research & $\begin{array}{l}\text { Lean Manufacturing in the Food and Beverage } \\
\text { Industry }\end{array}$ \\
\hline Jie and Gengatharen (2019) & SPSS & Food Supply Chain \\
\hline Castro and Posada (2019) & Questionnaire & Lean Manufacturing in the Baking Industry \\
\hline Dora et al. (2014) & Questionnaire & Lean Practices in SMEs \\
\hline Vlachos (2015) & Value Stream Mapping & Food Supply Chain \\
\hline Chen, Liu \& Oderanti (2020) & AHP & Food Supply Chain \\
\hline
\end{tabular}

In their study into lean management in food manufacturing, Lehtinen and Torkko (2005) discussed appropriate ways for applying lean concepts in a food-manufacturing company. They analyzed lean production, lean supply, and value stream mapping to understand the lean concept. Using a case study, they mapped out the collaboration that exists between the lean concept and supply chain management in the food chain. Chaplin and O'Rourke (2014) proposed a business development program, which covers the Lean Six Sigma concept in food manufacturing in the UK. Their study focuses on determining the gaps and benefits of the Lean Six Sigma program for marketing activities.

In their analysis of the benefits of lean manufacturing processes in the food and beverage industry, Kezia, Kumar, and Sai (2017) state that lean manufacturing leads to minimum waste and maximum utilization of resources. Castro and Posada (2019) focused on lean manufacturing in the baking industry to evaluate the results of lean techniques, which they did by way of a questionnaire. Ali. Tan, Suleiman, and Alam (2017) discussed ways of providing a balance between quality and cost with the help of lean approaches in the food industry. Their study looked at case studies in various companies in food supply chains. 
There are also different studies on lean management in food processing in the literature. Testa (2010) analyzed food processing based on the lean approach concept. The lean concept framework and Value Stream Mapping is discussed in the study to spread lean approach concept in mind. Noorwali (2013) focused on lean activities in food processing systems. His study includes Taguchi, a lean approach that is a simulation for minimizing variability levels in the food processing system.

Some studies have focused on lean management in food supply chains. Taylor (2006) analyzed techniques based on value-chain analysis and opportunities for strategic change in the agri-food supply chain in the UK relating to two red meat industry supply chains, and proposed an initial model for an integrated supply chain based on the application of the lean concept. Perez, Castro, Simons, and Gimenez (2010) analyzed the performance of a Catalan pork supply chain. They demonstrated the adaptation of the pork supply chain and lean approaches using multiple case study research and semi-structured interviews.

Zarei, Fakhrzad, and Paghaleh (2011) used QFD in their study on maximizing lean levels in the food supply chain. For this purpose, they analyzed a case study using fuzzy logic to show the practical results of the methodology. Chen, Liu \& Oderanti(2020) analyzed lean management in a food supply chain using the Analytical Hierarchy Process (AHP) to understand the opinions of experts with regard to lean thinking and objective performance. ScherrerRathje, Boyle, and Deflorin (2009) also state that lean management is critical both for the organization and for company supply chains. They highlighted critical rules for the lean concept, which provided the organizations in their study with lean knowledge, and analyzed two lean food processing equipment projects. Jie and Gengatharen (2019) focused on the Australian retail food sector in their study into how to improve the supply chain performance of small enterprises while reducing costs using lean thinking and knowledge sharing.

Manzouri, Rahman, Saibani, and Zain (2013) use a questionnaire with 300 food firms in Malaysia to evaluate the readiness level of lean practices in their supply chains. As a result, they discovered that more than half of the companies were not suitable for implementing lean approaches. Similarly, Vlachos (2015) tried to determine the compatibility of lean approaches and lean thinking in food supply chains and discovered that problems occur during the implementation of lean techniques. In this particular study, Value Stream Mapping is used for a case study that was based on a US tea company. Cox and Chicksand (2005) analyzed lean management implementation in the food industry using the case of a red meat supply chain.

Besseris (2014) discussed the Lean Six Sigma (LSS) concept and tried to provide LSS projects that can help those that introduce LSS with lean optimization efforts for addressing problems that are faced in food industry operations. A proposed model was adopted in a case study in the food industry. Lopes, Freitas, and Sousa (2015) put forward a study involving the implementation of lean management tools in two Portuguese food and drink companies. This study discussed the effect of lean management tools on these firms. Sreedharan and Raju (2016) systematically analyzed a literature review involving different sectors that adopt the lean management concept. They stated that there are fewer studies about lean management in the food sector than in other sectors.

Gellynck and Molnar (2009) studied the European food sector to determine product-level and chain-level relations based on governance structure. The study covered 54 companies in Italy, Belgium and Hungary. Using questionnaires Dora et al. (2014) focused on small and medium-size food enterprises to analyze the benefits of lean practices. With their study, they evaluated barriers to the implementation of lean techniques in small and medium-size European food enterprises.

Following the literature review, the research gap relating to lean and sustainable food operations is set out in the next section. 


\section{REDUCING FOOD WASTE USING LEAN AND SUSTAINABLE OPERATIONS}

Food waste threatens not only society but also the environment and the economy (Baig, Al-Zahrani, Schneider, Straquadine, \& Mourad, 2019). While ignoring sustainable operations in food waste threatens worker health, it also causes environmental problems, such as high carbon emissions and environmental pollution (Ritchie \& Roser, 2020). It also lowers efficiency in the food supply chain, leading to increased costs (FAO, 2011a). However, various articles in the existing literature indicate the need to adopt sustainable operations for dealing with food waste in order to ensure the survival of the planet and human well-being. Since food waste is a complex issue in sustainable operations, multidisciplinary thinking should be employed that considers economic, social and environmental aspects in equal harmony, whereas existing literature is predominantly motivated to consider only one or two of these aspects (Garcia-Garcia et al., 2017).

Lean management is needed to achieve this integration between the dimensions of sustainability. Lean thinking also benefits waste minimization, increases efficiency, and improves customer value. The Lean approach helps companies change their policies and build longer-term, sustainable systems. Thus, the lean approach is extremely important for managers from production to service. Moreover, due to its ability to identify waste, VSM can be easily linked to food-related losses and waste, and can be used to assess waste in the food sector (Wesana et al., 2019).

In complex production environments, analyzing the system with all its features is a challenge. In this case, the usefulness of VSM is proven under lean-based approaches in terms of a better and clearer visualization of the processes (Seth et al., 2017). VSM is a useful tool for approaching a system that requires "observing the whole" and rethinking the functions for improving processes. It is also useful for recognizing any disconnections between processes, and for improving performance after careful consideration (Henrique et al., 2016).

VSM also provides an overall view of all kinds of activities in the system and enables waste to be identified where production outputs, such as product quality, response times, and production costs can be revealed by its features (Lacerda, Xambre, \& Alvelos, 2016). Furthermore, VSM becomes most prominent because of its ability to quickly assess the state of production processes by their visual nature, allows quantification of production times, and reveals opportunities for improvement (Dinis-Carvalho et al., 2019).

Norton and Fearne (2009) revised the standard VSM methodology as Sustainable VSM by adding environmental performance indicators, like $\mathrm{CO}^{2}$ emissions and waste. Lean thinking, therefore, is an approach that is mainly used for reviewing and eliminating waste from all types of processes. Therefore, lean philosophy can also be adapted for dealing with food waste in a sustainable manner. In this sense, as one of the main methods of lean thinking, VSM can be implemented in food supply chains for minimizing food waste.

VSM is especially helpful in this study:

- For seeing the big picture of the system of interest,

- For understanding and prioritizing the main drivers of the waste-generating factors based on the valueadding and non-value adding classification of activities.

Even though articles have been written on the application of VSM in the food industry, there is still a gap in the literature, most of which does not consider the sustainability aspect, but rather process improvements that try to eliminate unnecessary inventory, shorten the production period, etc. In this study, however, the main purpose is to eliminate waste in a sustainable way either by identifying waste generating factors, or by increasing 
production performance. Unlike the existing literature, by incorporating the term "sustainability", this study aims to provide industry managers with promising multidisciplinary solutions for combining their economic, social and environmental objectives (Garcia-Garcia et al., 2017).

\section{METHODOLOGY: VALUE STREAM MAPPING}

As an important element of lean production, Value Stream Mapping (VSM) was first introduced by Rother and Shook (1998) as a functional method for reorganizing systems with a lean perspective (Lasa, Laburu, \& Vila, 2008). VSM can be used for identifying problems in a production system by redesigning it to eliminate waste and improve performance (Stadnica \& Litwin, 2019). VSM is a tool that can be defined as all the actions, including the valueadded and non-value-added actions, that are required for production flow from raw materials to the customer. It is used for identifying waste, which is also useful for establishing and monitoring green and sustainable practices (Faulkner \& Badurdeen, 2014).

VSM is a useful tool for visualizing and understanding the flow of information and materials along the value chain and gives a broad view of all activities in the production process (Lacerda et al., 2016). A very significant feature of VSM, unlike other process mapping methods, is that it documents not only basic product flows, but also the flow of information, including production scheduling and production information (Singh, Garg, \& Sharma, 2011). The main advantages of VSM are: it is an effective tool for implementing lean principles; it provides a link between production processes and supply chain activities by visualizing all flows; and it enables production planning, demand forecasting, and production scheduling to be integrated (Jasti, Kota, \& Sangwan, 2019).

Rother and Shook (1998) presented the stages of VSM application in five steps, which are:

(1) Selecting the product family;

(2) Modeling the current state map;

(3) Analyzing waste and proposing continuous improvement events, known as kaizen;

(4) Modeling the future state map;

(5) Making a work plan and composing it.

For the current state map, the main idea is data collection related to the current system for visualizing all the flows. The main steps for drawing up the current state map are: making observations and gathering data about customer requirements; presenting the physical flow of all processes with their data boxes and inventory details; mapping out the supply of materials; and determining the push and pull system and mapping out the information flow using specific graphical symbols for presenting the results (Masuti \& Dabade, 2019).

A guideline is also needed for presenting the future state map as well. Lasa et al. (2008) summarized this guideline as follows. First, the amount of production should be determined in accordance with product demand, where Takt time reflects the rate. Second, a continuous flow should be established insofar as this is possible. Third, a pull system should be used between work stations, where continuous flow is not possible. Fourth, the pacemaker process should be defined to command production of the various parts. Fifth, pacemaker process scheduling should be used for leveling product mix and product volume. Finally, overall process efficiency should be improved. 
In the following section, Value Stream Mapping is implemented in the food industry and a case study in the poultry industry is conducted using Value Stream Mapping.

\section{A CASE STUDY IN THE POULTRY INDUSTRY: PROBLEM DEFINITION AND THE CURRENT STATE MAP}

The case study was conducted in one of the biggest meat companies in Turkey that focuses particularly on turkeymeat products. The case company works with one supplier, which provides the company with live turkeys. Processes generally start with the turkeys being collected from the supplier, loading them into trucks, arriving at the company, unloading the trucks, cleaning the cages, continuing with the internal cutting processes, and ending with packing.

There are, however, many limitations related to capacity and animal welfare. For instance, turkeys must arrive at the company at night, since the death rate increases in the morning. The company does not like its employees working night shifts, however, because it reduces productivity, which leads to an increase in waiting times. At the same time, the supplier does not like having its turkeys collected at night because it wakes up the turkeys and increases their stress levels. In the current system, trucks wait for approximately 9 hours, and some 8-10 trucks arrive at the company every day. Truck capacity varies according to the gender of the turkeys, since females weigh less than males. In the current system, truck capacity for females, is 864 , and 432 for males. Another limitation is that trucks have to wait for each other to unload, and the current facility is unable to unload more than one truck at a time. The unloading process takes approximately 35-40 minutes for male turkeys, and 60 minutes for female turkeys. The cage-washing process also has to be finished before moving on to the next truck, a process that takes approximately five minutes. Another problem with the current system is that the company does not follow the first-in-first-out (FIFO) rule for the trucks arriving at the company for unloading. All these limitations increase waiting times. From this point of view, this study focuses especially on reducing the waiting times of trucks loaded with live turkeys to avoid lowering meat quality and reducing any weight loss due to stress caused by long waiting times.

Observations of the current system in the case company showed that waste can be categorized under two main headings: waste related to the supplier; and waste related to the company's internal processes.

The main waste for the supplier relates to cooperatives and to transportation processes. The supplier has several cooperatives that supply the company with livestock. This results in different distances between the cooperatives and the company and reveals a non-standard transportation process. The duration of the process for collecting livestock from the suppliers also varies and is a barrier when it comes to standardizing processes. The second important root cause of waste related to the supplier is the process by which the livestock is transported from the cooperatives to the company. There are problems related to the arrival time of the trucks at the company, and also to the number of trucks varying, which exposes problems related to scheduling.

Waste related to the company's internal processes can be categorized as waste related to: workers; waiting times; and caused by incompatibility between the working hours of the company and the supplier. To start with, the number of workers is not sufficient in the slaughterhouse, which results in long waiting times. Furthermore, in the current system workers are also not specialists in specific tasks, but have responsibilities during the entire process flow. This results in inefficient conditions in different processes. Another waste is caused by waiting times, and this occurs during two main processes. These are unnecessary waiting times between when the trucks arrive 
at the company and when the turkeys are unloaded, and between unloading the truck and waiting for the cages to be washed. The final problem related to internal processes is that the working hours of the company and the suppliers are different, and this results in an inconsistency between processes.

Based on this information, the current state map of the case study is shown in Figure 1. Due to the nature of the problem, and the focus area of this study, a two-stage VSM is drawn that shows both the processes of the suppliers and the internal processes. The map shows a total of 25 processes, but this study focuses particularly on the processes that precede the Shocking process ( $\left.\mathrm{P}_{4}\right)$. Value-added and non-value-added times are also presented in the current state map.

\section{Figure 1. Current State Map}

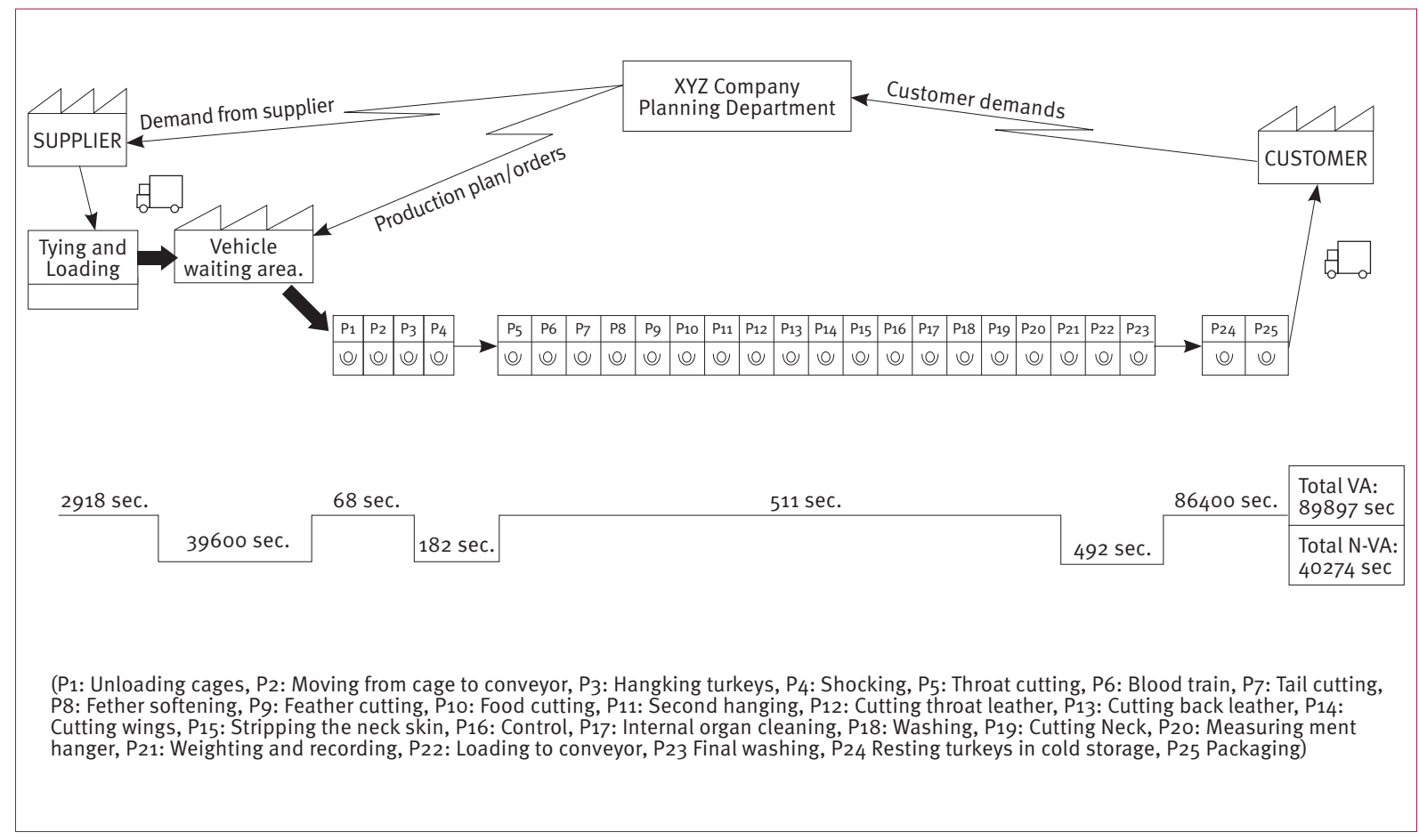

\section{Eliminating waste: The Future State Map}

The focus of this case study only covers the initial stages of VSM, which are the processes relating to the turkeys being collected from the supplier, arriving at the company, and being unloaded. For this reason, suggestions for improvements do not cover the processes in the slaughterhouse or the packing area. The following points are mentioned for the proposed future state map.

- Changing shift hours

- Late collection of turkeys

- Improving the tying and loading process using handling equipment

- The use of trailer trucks 
As mentioned before, one of the most significant reasons for the long waiting times is the difference between the working hours of the supplier and the company. By considering limitations related to animal welfare, meat quality and company policies, an arrangement can be suggested in terms of changing working hours for both the supplier and the company. After discussions between the company and the supplier, if the supplier starts collecting turkeys around 2 a.m. instead of 8:30 p.m., and the company introduces shift working and starts the slaughtering process at 5 a.m. instead of at 7 a.m., waiting times would reduce by around 3.5 hours. Therefore, the suggested initial improvement areas would be to change collection times and introduce shifts in the company.

Another improvement would be with regard to the tying and loading process, for which automatic handling equipment could be adopted. Manual handling is used in the current system, which results in extra effort on the part of employees and increases the stress level of the turkeys. Technological handling equipment can help eliminate movement waste, and also reduce processing time. An example of such equipment would be the TA 800 Turkey Loader, which would reduce processing time by $40 \%$, improve both worker and animal welfare, reduce staffrelated costs, and increase loading speed. An investment in this system would decrease the tying and loading process by 1167 seconds.

Trailer trucks could also be used for eliminating transportation waste and for carrying live animals more easily. The main advantages of a trailer truck are reducing the cost of additional vehicles, reducing maintenance costs, their usability for different purposes, providing additional carrying capacity and being more convenient during the loading process.

Based on these calculations, the ratio of non-value-added time to total process time is reduced from $30.9 \%$ to $17.8 \%$, which shows the result of general improvements in the supplier phase and in the waiting area in the company. In the following section, these results will be discussed and implications will be presented.

Figure 2. Future State Map

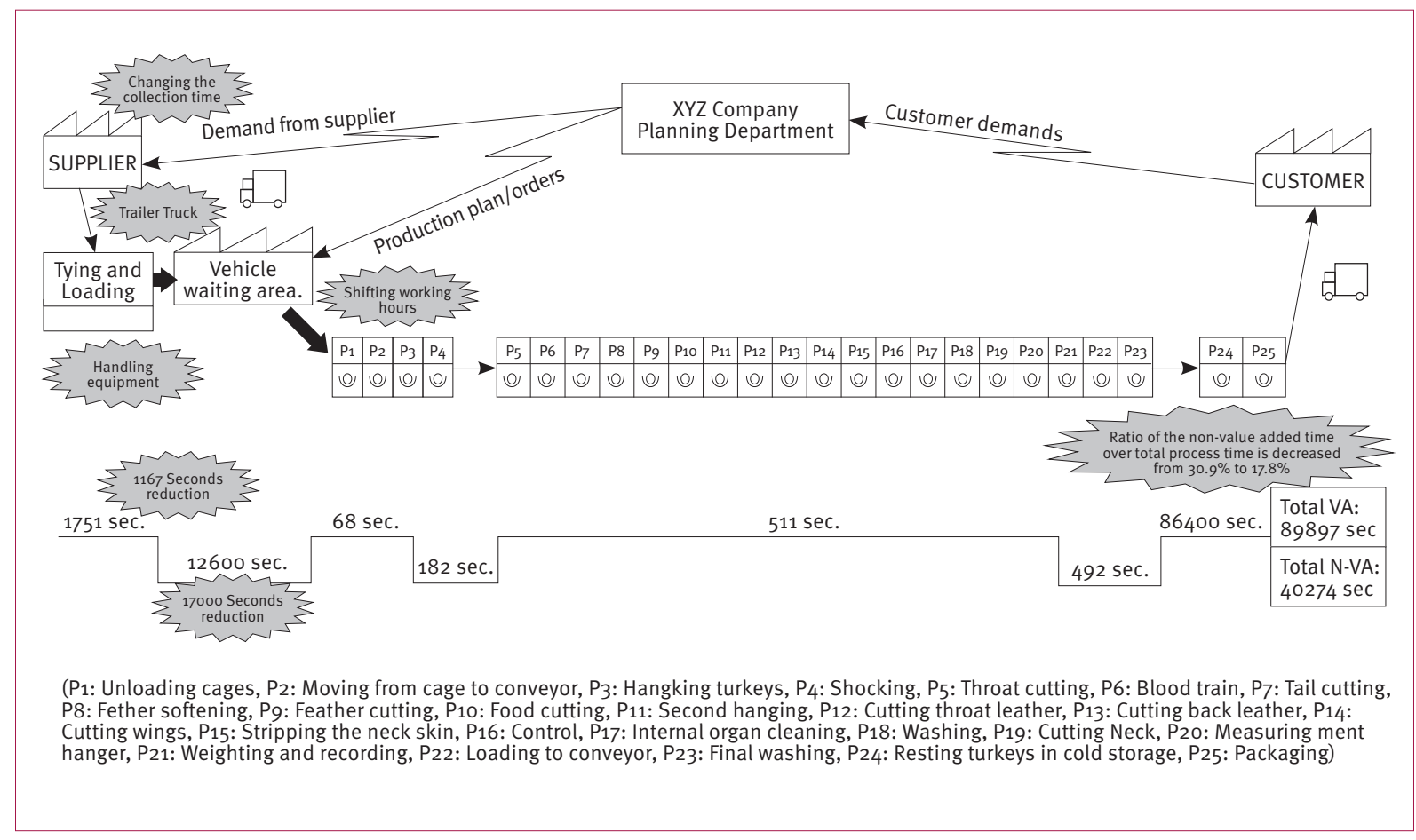




\section{CONTRIBUTIONS TO SUSTAINABLE FOOD OPERATIONS}

As mentioned in earlier sections, food supply chains create waste that is related to transportation, storage, handling, etc. Due to the waste that occurs in food supply chains, the social, economic and environmental concerns that are the dimensions of sustainability remain under threat (Cicatiello, Franco, Pancino, \& Blasi, 2016; Sharma, Mangla, Patil, \& Liu, 2019; Thyberg \& Tonjes, 2016; Vlachos, 2015). This waste prevents food operations from being sustainable. As a result, a lean philosophy and its practices can be a solution in food supply chains for minimizing waste (Ishangulyyev et al., 2019). This study provides social, environmental and economic benefits in sustainable food operations, as shown in Figure 3.

\section{Figure 3. Contributions to sustainable food operations}

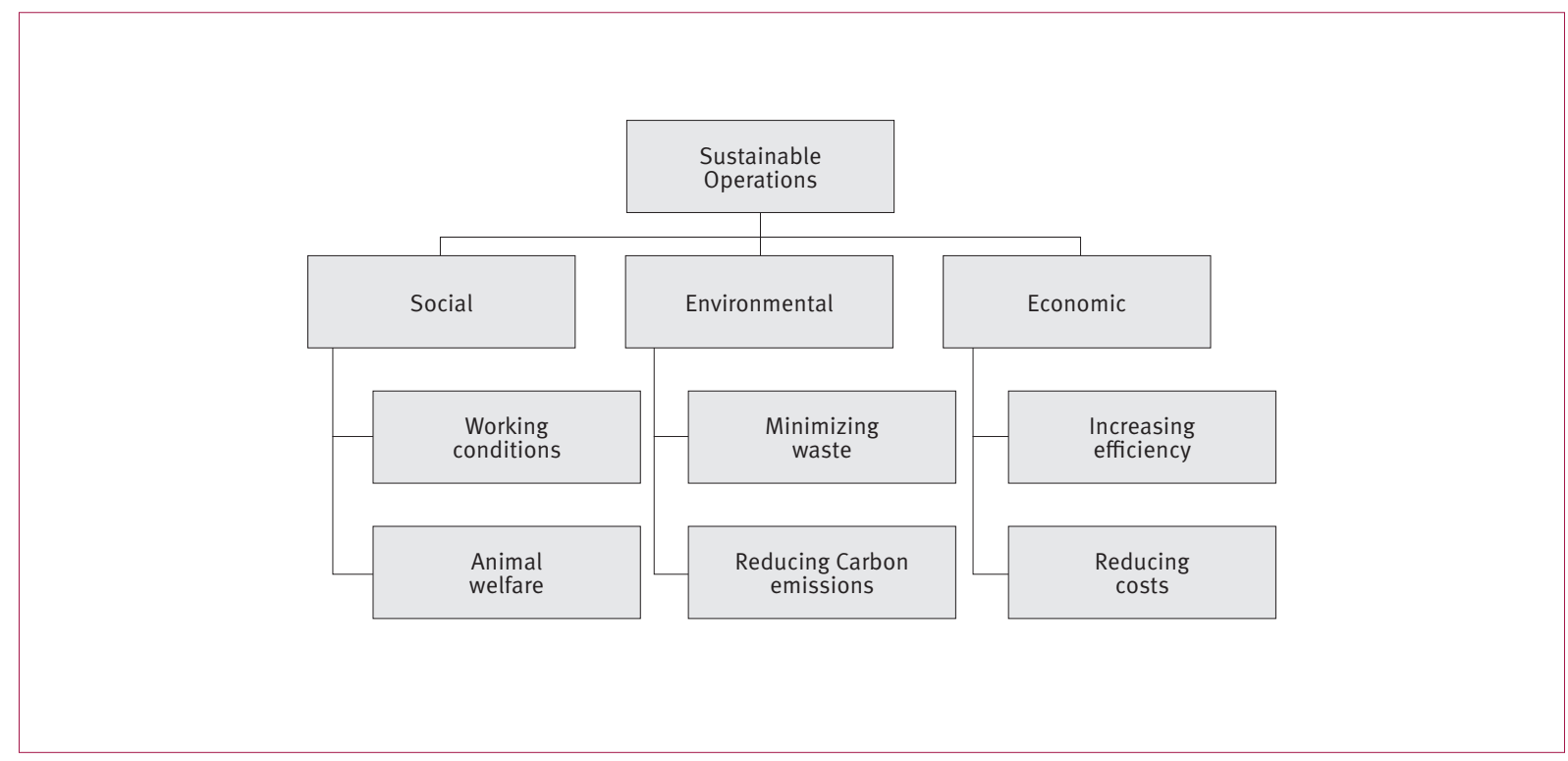

One of this study's important contributions to sustainable food operations covers the working conditions of suppliers and the company. With shifts being introduced into employee working hours, the efficiency of the process improves because of increases in the productivity and dependency of the workers. Moreover, as a result of the analysis, it is seen that due to the difference between the working conditions of the company and the suppliers, animal welfare decreases. With the suggestion of a time change resulting from the introduction of the lean method, it is expected that the animals will not be woken at night and that related stress levels will be avoided. It is expected, therefore, that animal welfare will increase. Improvements in working conditions in the company and the supplier, and increasing animal welfare are crucial contributions to social sustainability in food operations.

In addition to the social benefits, lean approaches also contribute to the savings by reducing costs (Nahmens \& Ikuma, 2012). The study's suggestions not only reduce personnel costs, but also reduce vehicle maintenance costs, because of the improvement in costs, and the increase in company efficiency. Therefore, these improvements contribute towards economic sustainability in food operations (Singh et al., 2019).

One of the most important contributions of this study is that it reduces and minimizes waste in food supply chains by considering environmental issues. The waste generated during the turkey collection stage by vehicles is minimized. Carbon emissions are also reduced through improved vehicle use and capacity. 
To sum up, the proposed study model not only contributes to the economy but also provides environmental and social benefits in sustainable food operations.

\section{IMPLICATIONS}

The results of this study cover the processes from the collection of the turkeys from suppliers until they are unloaded in the company. For managers, there are several important implications that can be addressed for minimizing waste in food supply chains. These implications can be mainly grouped under the following points; storage and retrieval systems, handling equipment, vehicle selection and interdisciplinary issues.

Storage and retrieval systems are an important area on which managers should focus, and they should be suitable for cold chain operations within food supply chains. Hence, the waste related to inappropriate warehouse management, such as lost, rotten, or perished food, can be prevented or minimized. The use of appropriate, technological storage and retrieval systems can, therefore, significantly contribute towards minimizing waste.

Handling equipment can increase the efficiency and effectiveness of food supply chain operations. Handling equipment can prevent losses by improving biosecurity and making transportation easy, and it is highly durable and easy to maintain. To be more specific and within the scope of this study, the handling process in poultry houses can be improved. When turkeys are being caught and handled, they may be bruised, injured, or even killed due to the unwitting violent responses of workers and rough handling. Turkeys may also injure themselves or their wings while they are trying to escape.

Another important managerial implication is related to the transportation process, which means that vehicle selection is an important concern. The following criteria can be considered for vehicle selection within food supply chains for minimizing waste during transportation; their current capacity and multi-purpose features, convenient loading and unloading, flexibility for increasing capacity, and their appropriateness for cold chain operations.

Food supply chain management involves many stakeholders and requires knowledge of various fields. Interdisciplinary cooperation and collaboration, therefore, is crucial because of the nature of the complex structure of food supply chain. The purpose of minimizing waste in food supply chains requires the involvement of experts from various disciplines. For example, animal welfare should be considered during food supply operations to prevent losses and waste. In this sense, the expertise of veterinary and agricultural engineers can be used.

The term "value-added" in VSM can also be expanded in regards to sustainability. Therefore, it can deal not only with waste, but also with circularity or energy consumption.

To sum up, managers should not only employ lean principles in inhouse operations in the facility, but at every stage in the food supply chain. They should analyze each process along the chain and implement a lean philosophy and its tools in order to minimize food waste.

There are also implications for policymakers aiming to reduce food waste. Current or future rules and regulations should contain clear and holistic control mechanisms, and a "lean philosophy" should be the basis of these control mechanisms. Food waste should be tracked, quantified, and controlled throughout the food supply chain covering all processes and neglecting none of them. Clear targets can be established at each stage of the supply chain that are specific and suitable for each food category. Lean tools can be suggested and even taught to companies by governments or local authorities, and then companies will be controlled with regard to their usage and performance. 
VSM can be used as a method for measuring and evaluating the sustainability performance of corporate food supply chains. This situation can be the basis of the incentive, control and inspection mechanisms of companies. This can be offered to policymakers as a tool.

\section{CONCLUSION}

According to the statistics, food waste is increasing worldwide. Particularly in emerging economies like Turkey, the increase in food waste is threatening the economic, social, and environmental aspects of countries. Due to its nature, food waste is a complex problem that requires holistic and interdisciplinary approaches. A lean philosophy is the approach that offers value to both customers and institutions by continuously improving processes and minimizing waste.

This study looked at ways of minimizing food waste in emerging economies with the help of lean philosophy and its tools, which were implemented in a poultry industry in Turkey. The current state map is prepared for processes that start with the collection of the turkeys from suppliers and conclude when they are slaughtered in the company, with VSM being implemented for these processes. Various improvements for sustainable operations are suggested for food supply chain processes involving the implementation of VSM. The results were presented and related implications for both policymakers and managers were set out.

According to the results, storage and retrieval systems are an essential process in food supply chain operations, and should be managed properly. With improvements in handling equipment, the efficiency and effectiveness of the food supply chain operations also improve by eliminating injuries that occur during animal capture with the use of proper handling equipment. It was shown that the transportation process is crucial in food supply chains. Proper transportation processes lead to improvements in current capacity, and convenient loading, and unloading, etc.

Although this study was developed considering emerging economies, it can be further extended to include developed economies. Future studies can be carried out by integrating the circular economy with lean and sustainable food operations. The proposed methodology can also be combined with Industry 4.0 and digitization. The current study can be integrated with blockchain technologies to improve traceability, and also applied to other types of food production and to other food industries.

One of the limitations of the study is that it was conducted in only one sector. However, the proposed methodology is generic and can be extended to other industries in the food sector. The context of the case study was limited to upstream operations, but can easily be extended to include downstream operations. The top management in companies should dedicate themselves to sustainability because the food industry has a complex structure and it is difficult to gather proper data for analyzing its operations. 


\section{REFERENCES}

Ali, M. H., Tan, K. H., Suleiman, N., \& Alam, S. S. (2017). The traction of lean production on Halal food integrity. MOJ Food process Technol, 5(4), 136. doi: 10.15406/mojfpt.2017.05.00136

Baig, M. B., Al-Zahrani, K. H., Schneider, F., Straquadine, G. S., \& Mourad, M. (2019). Food waste posing a serious threat to sustainability in the Kingdom of Saudi Arabia: A systematic review. Saudi Journal of Biological Sciences, 26(7), 1743-1752. doi: 10.1016/j.sjbs.2018.06.004

Besseris, G. (2014). Multi-factorial lean six sigma product optimization for quality, leanness and safety: A case study in food product improvement. International Journal of Lean Six Sigma, 5(3), 253-278. doi: 10.1108/IJLSS-06-2013-0033

Castellini, C., Bastianoni, S., Granai, C., Bosco, A. D., \& Brunetti, M. (2006). Sustainability of poultry production using the emergy approach: Comparison of conventional and organic rearing systems. Agriculture, Ecosystems and Environment, 114, 343-350. DOI: 10.1016/j.agee.2005.11.014

Castro, M., \& Posada, J. (2019, May 9). Implementation of lean manufacturing techniques in the bakery industry in Medellin. Gestão \& Produção, 26(2), e2505. doi: 10.1590/0104-530x2505-19

Castro, M. Del R. Q., \& Posada, J. G. A. (2019). Implementation of lean manufacturing techniques in the bakery industry in Medellin. Gestão e Produção, 26(2), 1-9. doi: 10.1590/0104530X-2505-19

Chaplin, L., \& O'Rourke, S. T. J. (2014). Lean Six Sigma and marketing: A missed opportunity. International Journal of Productivity and Performance Management, 63(5), 665-674. doi: 10.1108/IJPPM-09-2013-0155

Chen, H., Liu, S., \& Oderanti, F. (2020). A knowledge network and mobilisation framework for lean supply chain decisions in agri-food industry. Supply Chain and Logistics Management: Concepts, Methodologies, Tools, and Applications. doi: 10.4018/978-1-7998-0945-6.cho18

Chronéer, D., \& Wallström, P. (2016). Exploring waste and value in a lean context. International Journal of Business and Management, 11(10), 282. doi: 10.5539/ijbm.v11n1op282

Cicatiello, C., Franco, S., Pancino, B., \& Blasi, E. (2016). The value of food waste: An exploratory study on retailing. Journal of Retailing and Consumer Services, 30(C), 96-104. doi: 10.1016/j.jretconser.2016.01.004

Cox, A., \& Chicksand, D. (2005). The limits of lean management thinking: Multiple retailers and Food and farming supply chains. European Management Journal, 23(6), 648-662. doi: 10.1016/j.emj.2005.10.010
Dinis-Carvalho, J., Monteiro, M., \& Macedo, H. (2019, November). Continuous Improvement System: Team Members' Perceptions. In European Lean Educator Conference (pp. 201-210). Springer, Cham.

Dekier, Ł. (2012). The origins and evolution of lean management system. Journal of International Studies, 5(1), 46-51. doi: 10.14254/2071-8330.2012/5-1/6

Dora, M., Goubergen, D. Van, Kumar, M., Molnar, A., \& Gellynck, X. (2014). Application of lean practices in small and mediumsized food enterprises. British Food Journal, 116(1), 125-141. doi: 10.1108/BFJ-05-2012-0107

Faulkner, W., \& Badurdeen, F. (2014). Sustainable Value Stream Mapping (Sus-VSM): Methodology to visualize and assess manufacturing sustainability performance. Journal of Cleaner Production, 85(15), 8-18. doi: 10.1016/j.jclepro.2014.05.042

Food and Agriculture Organization of the United Nations. (2011a). Global food losses and food waste: Extent, causes and prevention. International Congress SAVE FOOD! at Interpack 2011, Düsseldorf, Germany. Retrieved from www.fao.org/ docrep/014/mbo6oe/mbo6oe.pdf

Food and Agriculture Organization of the United Nations (2011b). Global food losses and food waste: Extent, causes and prevention. Retrieved from https://ec.europa.eu/ knowledge 4 policy/publication/global-food-losses-foodwaste-extent-causes-prevention_en

Food and Agriculture Organization of the United Nations (2015). FAO Statistical Pocketbook, Rome, Italy.

Garcia-Garcia, G., Woolley, E., Rahimifard, S., Colwill, J., White, R., \& Needham, L. (2017). A methodology for sustainable management of food waste. Waste and Biomass Valorization, 8(6), 2209-2227. doi: 10.1007/S12649-016-9720-0

Gellynck, X., \& Molnar, A. (2009). Chain governance structures: The European traditional food sector. British Food Journal, 111(8), 762e775. doi: 10.1108/00070700910980900

Gimenez, E. H., Shattuck, A., Altieri, M., Herren, H., \& Gliessman, S. (2010). We already grow food for 10 billion people... and still can't end hunger. Journal of Sustainable Agriculture, 36, 595-598. doi: 10.1080/10440046.2012.695331

Gustavsson, J., Cederberg, C., Sonesson, U., Otterdijk, R. Van, \& Meybeck, A. (2011). Causes and prevention of food losses and waste. Global Food Losses and Food Waste, Study conducted for thelnternational Congress SAVE FOOD! at Interpack 2011 Düsseldorf, Germany, FAO, 2011, 1-8. 
Gooch, M., Felfel, A., \& Marenick, N. (2010). Food waste in Canada. Value Chain Management Centre, George Morris Centre, November.Henrique, D. B., Rentes, A. F., Godinho Filho, M., \& Esposto, K. F. (2016). A new value stream mapping approach for healthcare environments. Production Planning \& Control, 27(1), 24-48. doi: 10.1080/09537287.2015.1051159

Ingrao, C., Faccilongo, N., Gioia, L. Di, \& Messineo, A. (2018). Food waste recovery into energy in a circular economy perspective: A comprehensive review of aspects related to plant operation and environmental assessment. Journal of Cleaner Production, 184(20), 869-892. doi: 10.1016/j.jclepro.2018.02.267

Institution of Mechanical Engineers. (2013). Global food waste not want not. Retrieved from https://www.imeche.org/policyand-press/reports/detail/global-food-waste-not-want-not

Ishangulyyev, R., Kim, S., \& Lee, S. H. (2019). Understanding food loss and waste-why are we losing and wasting food? Foods, 8(8), 297. doi:10.3390/foods8080297

Jasti, N. V. K., Kota, S., \& Sangwan, K. S. (2019). An application of value stream mapping in auto-ancillary industry: A case study. The TQM Journal, 32(1), 162-182. doi: 10.1108/TQM-11-20180165

Jie, F., \& Gengatharen, D. (2019). Australian food retail supply chain analysis. Business Process Management Journal, 25(2), 271-287. doi: 10.1108/BPMJ-03-2017-0065

Ju, M., Osako, M., \& Harashina, S. (2017). Food loss rate in food supply chain using material flow analysis. Waste Manag, 61, 443e454. doi: 10.1016/j.wasman.2017.01.021

Kayikci, Y., Ozbiltekin, M., \& Kazancoglu, Y. (2019). Minimizing losses at red meat supply chain with circular and central slaughterhouse model. Journal of Enterprise Information Management, 33 (4), 791-816. doi: 10.1108/JEIM-01-20190025

Kezia, P., Kumar, K. S., \& Sai, B. L. N. (2017). Lean manufacturing in food and beverage industry. International Journal of Civil Engineering and Technology, 8(5), 168-174V

Kumar, A., Mangla, S. K., Kumar, P., \& Karamperidis, S. (2020). Challenges in perishable food supply chains for sustainability management: A developing economy perspective. Business Strategy and the Environment, 29(5), 1809-1831. doi: 10.1002/ bse. 2470

Kumar, D., \& Kalita, P. (2017). Reducing postharvest losses during storage of grain crops to strengthen food security in developing countries. Foods, 6(1), 8. Doi: 10.3390/ foods6010008

Kumm, K. I. (2002). Sustainability of organic meat production under Swedish conditions. Agriculture, Ecosystems and Environment, 88(1), 95-101. doi: 10.1016/s01678809(01)00156-6
Kummu, M., Moel, H., Porkka, M., Siebert, S., Varis, O., \& Ward, P.J. (2012). Lost food, wasted resources: Global food supply chain losses and their impacts on freshwater, cropland, and fertiliser use. Science of the Total Environment, 438(1), 477489. doi: 10.1016/j.scitotenv.2012.08.092

Lacerda, A. P., Xambre, A. R., \& Alvelos, H. M. (2016). Applying value stream mapping to eliminate waste: A case study of an original equipment manufacturer for the automotive industry. International Journal of Production Research, 54(6), 17081720. https://doi.org/10.1080/00207543.2015.1055349

Lasa, I. S., Laburu, C. O., \& Vila, R. de C. (2008). An evaluation of the value stream mapping tool. Business Process Management Journal, 14(1), 39-52. doi: 10.1108/14637150810849391

Lehtinen, U., \& Torkko, M. (2005). The lean concept in the food industry: A case study of contract a manufacturer. Journal of Food Distribution Research, 36(3), 57-67. doi: 10.22004/ ag.econ. 27759

Liu, Q., Yang H., \& Xin, Y. (2019). Applying value stream mapping in an unbalanced production line: A case study of a Chinese food processing enterprise. Quality Engineering, 32(1). doi: 10.1080/08982112.2019.1637526.

Lopes, R. B., Freitas, F., \& Sousa, I. (2015). Application of lean manufacturing tools in the food and beverage industries. Journal of Technology Management and Innovation, 10(3), 120-130. doi: 10.4067/s0718-27242015000300013

Mahalik, N. P., \& Nambiar, A. N. (2010). Trends in food packaging and manufacturing systems and technology. Trends in Food Science \& Technology, 21(3), 117-128. doi: 10.1016/j. tifs.2009.12.006

Mangla, S. K., Luthra, S., Rich, N., Kumar, D., Rana, N. P., \& Dwivedi, Y. K. (September, 2018). Enablers to implement sustainable initiatives in agri-food supply chains. International Journal of Production Economics, 203, 379-393. doi: 10.1016/j. ijpe.2018.07.012

Manzouri, M., Rahman, M. N. Ab, Saibani, N., \& Zain, C. R. Che M. (2013). Lean supply chain practices in the Halal food. International Journal of Lean Six Sigma, 4(4), 389-408. doi: 10.1108/IJLSS-10-2012-0011

Masuti, P. M., \& Dabade, U. A. (2019). Lean manufacturing implementation using value stream mapping at excavator manufacturing company. Materials Today: Proceedings, 19, 606-610

Nahmens, I., \& Ikuma, L. (2012). Effects of lean construction on sustainability of modular homebuilding. Journal of Architectural Engineering, 18, 155-163. doi: 10.1061/(asce) ae.1943-5568.0000054 
Noorwali, A. (2013). Apply lean and Taguchi in different level of variability of food flow processing system. Procedia Engineering, 63, 728-734. doi: 10.1016/j.proeng.2013.08.285

Norton, A., \& Fearne, A. (2009). Sustainable value stream mapping in the food industry. In: Waldron, Keith, ed. Handbook of Waste Management and Co-Product Recovery in Food Processing. Woodhead Publishing, Cambridge

Östergren, K., Gustavsson, J., Bos-Brouwers, H., Timmermans, T., Hansen, O.-J., Møller, H., ... Redlingshöfer, B. (2014). FUSIONS Definitional Framework for Food Waste. FUSIONS, Göteborg, Sweden

Parfitt, J., Barthel, M., \& Macnaughton, S. (2010). Food waste within food supply chains: Quantification and potential for change to 2050. Philosophical Transactions of the Royal Society of London, Series B. Biological Sciences, 365(1554), 3065-3081. doi:10.1098/rstb.2010.0126v

Perez, C., Castro, R. de, Simons, D., \& Gimenez, G. (2010). Development of lean supply chains: A case study of the Catalan pork sector. Supply Chain Management: An International Journal, 15(1), 55-68. doi: 10.1108/13598541011018120

Ritchie, H., \& Roser, M. (2020). Environmental impacts of food production. Retrieved from https://ourworldindata.org/ environmental-impacts-of-food

Rother, M., \& Shook, J. (1998). Learning to see: Value stream mapping to add value and eliminate muda. Cambridge, MA: Lean Enterprise Institute

Scherrer-Rathje, M., Boyle, T. A., \& Deflorin, P. (2009). Lean, take two! Reflections from the second attempt at lean implementation. Business Horizons, 52(1), 79-88. doi: 10.1016/j.bushor.2008.08.004

Seth, D., Seth, N., \& Dhariwal, P. (2017). Application of value stream mapping (VSM) for lean and cycle time reduction in complex production environments: a case study. Production Planning \& Control, 28(5), 398-419. doi: 10.1080/09537287.2017.1300352V

Sharma, Y., Mangla, S., Patil, P., \& Liu, S. (2019). When challenges impede the process: For circular economy-driven sustainability practices in food supply chain. Management Decision, 57(4), 995-1017. doi: 10.1108/md-09-2018-1056

Singh, B., Garg, S. K., \& Sharma, S. K. (2011). Value stream mapping: literature review and implications for Indian industry. The International Journal of Advanced Manufacturing Technology, 53(5-8), 799-809. doi: 10.1007/s00170-010-2860-7

Singh, R. K., Luthra, S., Mangla, S. K., \& Uniyal, S. (2019). Applications of information and communication technology for sustainable growth of SMEs in India food industry. Resources, Conservation and Recycling, 147, 10-18. doi: 10.1016/j.resconrec.2019.04.014
Sreedharan, R., \& Raju, R. (2016). A systematic literature review of Lean Six Sigma in different industries. International Journal of Lean Six Sigma, 7(4), 430-466. doi:10.1108/ijlss-12-2015-0050

Stadnicka, D., \& Litwin, P. (February, 2019). Value stream mapping and system dynamics integration for manufacturing line modelling and analysis. International Journal of Production Economics, 208, 400-411. doi: 10.1016/j.ijpe.2018.12.011

Tatlidil, F. F., Dellal, I., \& Bayramoglu, Z. (2013). Food losses and waste in Turkey. Food and Agriculture Organization of the UN, Food Losses and Waste in Europe and Central Asia, component of the Agrarian Structures Initiative, a regional program of FAO in Europe and Central Asia.

Taylor, D. H. (2006). Strategic considerations in the development of lean agri-food supply chains: A case study of the UK pork sector. Supply Chain Management, 11(3), 271-280. doi: $10.1108 / 13598540610662185$

Testa, N. M. (2010). Lean food processing. Cereal Foods World, 55(4), 172-175. doi: 10.1094/CFW-55-4-0172

The Standing Committee for Economic and Commercial Cooperation of the Organization of the Islamic Cooperation. (2017, January). Reducing Food Waste in the OIC Countries. Retrieved from http://www.sbb.gov.tr/wp-content/ uploads/2018/11/Reducing_Food_Waste_in_the_OIC_ Countries.pdf

Thyberg, K. L., \& Tonjes, D. J. (January, 2016). Drivers of food waste and their implications for sustainable policy development. Resources, Conservation and Recycling, 106, 110-123. doi: 10.1016/j.resconrec.2015.11.016

Turkish Republic Ministry of Industry and Trade. (2018). Turkey Waste Report. Retrieved from https://www.trade.gov.tr/ statistics/statistics

United Nations High Commissioner for Refugees. (2019). Global trends forced displacement in 2018. Retrieved from www. unhcr.org/5c6fb2do4

Verghese, K., Lewis, H., Lockrey, S., \& Williams, H. (2015). Packaging's Role in minimizing food loss and waste across the supply chain. Packag. Technol. Sci. Published online in Wiley Online Library (wileyonlinelibrary.com) doi: 10.1002/pts.2127

Verma, M., Plaisier, C., van Wagenberg, C. P., \& Achterbosch, T. (2019). A systems approach to food loss and solutions: Understanding practices, causes, and indicators. Towards Sustainable Global Food Systems, 11(3), 102-120. doi: $10.3390 /$ su11030579

Vlachos, I. (2015). Applying lean thinking in the food supply chains: A case study. Production Planning \& Control, 26(16), 1351-1367, doi: 10.1080/09537287.2015.1049238 
Wesana, J., Gellynck, X., Dora, M. K., Pearce, D., \& De Steur, H. (2019). Measuring food and nutritional losses through value stream mapping along the dairy value chain in Uganda. Resources, Conservation and Recycling, 150, 104416. doi: 10.1016/j.resconrec.2019.104416

World Food Program USA. (2019). "8 Facts to Know About Food Waste and Hunger" Retrieved from https://www.wfpusa.org/ stories/8-facts-to-know-about-food-waste-and-hunger/

Wunderlich, S. M., \& Martinez, N. M. (2018). Conserving natural resources through food loss reduction: Production and consumption stages of the food supply chain. International Soil and Water Conservation Research, 6(4), 331-339. doi: 10.1016/j.iswcr.2018.06.002
Yildirim, H., Capone, R., Karanlik, A., Bottalico, F., Debs, P., \& Bilali, H. El. (2016). Food wastage in Turkey: An exploratory survey on household food waste. Journal of Food and Nutrition Research, 4(8), 483-489. doi: 10.12691/jfnr-4-8-1

Zarei, M., Fakhrzad, M. B., \& Paghaleh, M. J. (2011). Food supply chain leanness using a developed QFD model. Journal of Food Engineering, 102(1), 25-33. doi: 10.1016/j. jfoodeng.2010.07.026

Zhao, G., Liu, S., Lopez, C., Chen, H., Lu, H., Mangla, S. K., \& Elgueta, S. (2020). Risk analysis of the agri-food supply chain: A multi-method approach. International Journal of Production Research, 58(16), 2020, 4851-4876. doi: $10.1080 / 00207543.2020 .1725684$

\section{AUTHORS' CONTRIBUTIONS}

The authors declare that they participated in all stages of development of the manuscript. Dr. Esra EKINCI worked on the conceptualization and theoretical-methodological approach. The theoretical review was conducted by Research Assistant Yesim Deniz Ozkan-Ozen \& Research Assistant Melisa Ozbiltekin-Pala. Data collection was coordinated by Research Assistant Melisa Ozbiltekin-Pala and data analysis was conducted by Dr. Esra Ekinci. Prof. Yigit Kazancoglu encouraged Research Assistant Melisa Ozbiltekin-Pala and Research Assistant Yesim Deniz Ozkan-Ozen to investigate and supervised the findings of this work. All authors worked together in the writing and final revision of the manuscript. 